\title{
Dividend and Bank Performance in India: Evidence using Panel Data Analysis
}

\author{
Venkata Mrudula Bhimavarapu, Shailesh Rastogi
}

\begin{abstract}
Dividend has been a matter of concern since the concept of limited liability of the firms came to existence. The uncertainty regarding dividend policy is supposed to hunker down unless we move away from whack-a-mole approach to a long-winded solution to the problem of dividend policy. The issue gets exacerbated because of inclination towards the valuation by the people who call the shots in the firms. This paper explores the association of dividend with the rising NPAs in the Indian banks. The findings of the paper are the testimony to the fact that dividend policy in the banks has issues and need to be checked and corrected. It is recommended in the paper to decouple dividends from the NPA by linking dividend policy with free cash flow. It is also recommended to adopt DVR shares to cater to the aspirations of those investors who do look for consistent dividend policy irrespective of the performance of the banks in a particular year.
\end{abstract}

Key Words: Banks, Dividend Policy, Panel Data, Performance.

\section{INTRODUCTION}

$\mathrm{D}_{\mathrm{i} \text { in }}$ vidend policy is one of ongoing debate in the corporate world [2]. As a matter of corporate finance, the dividend should be given when a firm has excess cash than what the firm needs to their reinvestment needs [5]. However, there is no unanimous evidence for residual dividend policy as the most sought-after policy in India or in any other nation [20]. However, the stability of dividend pay-out as a policy has more acceptance in the corporate world as well as to the shareholders [12],[13],[15]. Due to umpteen reasons, corporates may want to stick to a consistent dividend policy. This policy of stable dividends may be detrimental to the long-run performance and even the long-term solvency of the firm. This policy is in direct conflict with the basic governance and profit distribution policy of corporate finance [2],[9]. One of the obvious interpretations of this stable dividend policy is that a firm pays the same dividend whether the firm makes a profit or not. A firm tries to stick to its stable dividend policy even if the firm is financially distressed [9],[10]. It is not that the issue of stable dividend policy is a matter of fact for a particular sector. Rather it slights across the sectors [19].

Manuscript received on August 24, 2021.

Revised Manuscript received on August 29, 2021.

Manuscript published on September 30, 2021.

* Correspondence Author

Venkata Mrudula Bhimavarapu*, Ph.D. Scholar, Symbiosis Institute of Business Management, Pune; Symbiosis International (Deemed University), Pune, India. Email: mrudulabhimavarapu@gmail.com

Dr. Shailesh Rastogi, Professor, Symbiosis Institute of Business Management, Pune; Symbiosis International (Deemed University), Pune, India.Email: krishnasgdas@gmail.com

(C) The Authors. Published by Blue Eyes Intelligence Engineering and Sciences Publication (BEIESP). This is an open access article under the CC BY-NC-ND license (http://creativecommons.org/licenses/by-nc-nd/4.0/)
However, for a few sectors, which may be in distress, stable dividend policy can stifle their inorganic as well as organic growth. It is not that the problem is not discussed in the literature before. There are many studies to explore the most optimum dividend policy [2],[3],[7],[12]. Despite voluminous literature on the topic, the issue of optimum dividend policy remains unresolved. This study is an attempt to understand the issue of dividend policy viz-a-viz bank performance in India. NPA is one of the indicators of the bank performance [28]. We believe that the problem of dividend policy in banks can be understood well by finding the association between dividend pay out and NPA. If a firm is paying dividend despite the rising NPA, it can be considered that consistent dividend policy is not helping the banks to come out of morass and labyrinth of NPA. The varied issues in the banks regarding their performance is the main motivation for this study. This study choses to look for the problem of the performance of the banks from the perspective of the dividend policy. Hence the objective of this study is to determine the impact of dividend payment on the NPA. Although both do not seem to have any logical relevance, the indirect association can be subtle and fritter away possibility of the better performance if checked properly. As a dividend policy subject to the profitability can add more value than dividend payment may not increase the NPA levels. On the contrary, increase in NPA due to dividend implies that the consistent dividend policy bereft of the consideration of profitability depletes the value of the bank. Surprisingly, it is found that dividends lead to increase in the NPA levels. The results corroborate the perception that consistent dividend policy is detrimental to the value proposition of the banks in India. Such results are not observed in the literature. Hence, findings of the papers add novelty and a unique perspective to the dividend policy and performance of the banks. The findings of the study can have the wider scope and can help the issue of dividend and NPA in banks across all the emerging economies. The scant literature will be benefitted by the findings of the current paper. The main implication of the findings of the study is to help policy makers and decision makers in the banks to consider the adverse impact of consistent dividend policy on the value of the banks. The rest of the paper is arranged in the six sections including the Introduction section. The next section is on theoretical background and hypotheses formulation. The third section is on data and methodology followed by fourth section on the results. The fifth section is on discussion of the finding of the current paper with respect to the earlier similar studies. The study is concluded in the sixth and last section. 


\section{Dividend and Bank Performance in India: Evidence using Panel Data Analysis}

\section{THEORETICAL BACKGROUND, LITERATURE REVIEW AND HYPOTHESES FORMULATION}

Bank and its performance are a subject matter of great debate and scholarly discourse [4],[6],[37]. The technological advancement in the banks build the right ecosystem to create futuristic banks which can handle the uncertainties of the future in more effective way [27],[29],[30],[31],[32]. Banks do have their share of issues regarding governance and disclosures [14], [35], [36]. The issue of market efficiency [16],[17],[18], volatility [22],[23],[33],[34] and derivative market also have its impact on the performance of the banks [21],[24], [25], [26], [34], [38]. But the perspective of dividend is usually dodged by the academicians and researchers. This study is an attempt to bridge the gap and provide the empirical evidence regarding the dividend policy and performance of the banks especially when performance of the banks is visualized from the NPA point of view.

Thus, the following hypothesis is framed:

$\mathrm{H}_{1}$ : Dividends are not associated with the NPA levels in the banks.

\section{DATA AND METHODOLOGY}

\section{A. Data and Variables}

Panel Data of 34 Indian banks are taken up over the five years period is taken up (2015-2019). The variables undertaken in the study are: 1) NPA (non-performing assets) of the banks; 2) Dividend pay put ratio (DPR); and 3) DebtRatio (DR). NPA is the amounts of advances which are defaulted for more than 3 months. DPR is defined as dividend pay out ratio to ascertain the dividend [1] payment in the banks. DR is as a control variable to control for the long-term liquidity in the banks [8],[11].

\section{B. Methodology}

Panel data modelling is used to explicate the impact of DPR on the NPA of the banks while long term liquidity is controlled. Following static model is made and estimated:

$N P A_{i t}=\beta_{0}+\beta_{1} D P R_{i t}+\beta_{2} D R_{i t}+v_{i t}$ Eq-1

Where

$\beta_{0}, \beta_{1}, \beta_{2}$ are coefficients

$v_{i t}$ is combined error term $\left(\lambda_{\mathrm{i}}+\mathrm{u}_{\mathrm{it}}\right)$; $\lambda_{\mathrm{i}}$ is individual error variance and the $\mathrm{u}_{\mathrm{it}}$ is regular idiosyncratic error term

The following dynamic model is estimated

$$
\begin{aligned}
& N P A_{i t}=\beta_{0}+\beta_{1} N P A_{i(t-1)}+\beta_{2} D P R_{i t}+\beta_{3} D R_{i t}+u_{i t} \\
& \text { Eq-2 }
\end{aligned}
$$

Where in addition to the equation 1 (the static model), lag of the endogenous variable is also present on the right-hand side of the equation. The error term is regular idiosyncratic error term.

\section{RESULTS}

Static panel data analysis results are reported in Table 1 . The proposed specification of the model (Equation 1) is estimated with the help of STATA 15. On checking for the individual effect of the cross-sectional data (banks), it is found that both the effects (Fixed effect and Random effect) are significant. Furthermore, RE model is estimated as Hausman test cannot be rejected. We estimated robust standard error as the RE static panel data model has the issues of heteroscedasticity as null of Wald test of heteroscedasticity of no heteroscedasticity is rejected (whereas there is no problem of autocorrelation in the data). The explanatory variable DPR is significant as the associated p-value of the DPR's coefficient is less than $5 \%$ (at $5 \%$ level of significance). The control variable, debt ratio is also significant. Hence the outcome of static panel data results can be recapitulated as follows: the non-performing assets have positive significant association with DPR while controlling for the debt-ratio in the banks.

\begin{tabular}{|c|c|c|}
\hline & DV: NPA & DV: NPA (Robust Estimates) \\
\hline Constant & $.3156,2.7486(.909)$ & $.3156,1.8621(.865)$ \\
\hline DPR & $.0022, .0031(.468)$ & $.0022 *, .0011(.0500$ \\
\hline DR & 4.4294, $3.0068(.141)$ & $4.4294 *, 2.1087(.036)$ \\
\hline F-test (Model) & $8.91 *(.0116)$ & $8.91 *(.0116)$ \\
\hline R-Square & .0102 & .0102 \\
\hline F-test Fixed Effect & $17.65 *(.0000)$ & \\
\hline Breush-Pagan Test & $123.17 *(.0000)$ & \\
\hline Hausman Test & $.01(.9048)$ & \\
\hline Theta & .7583 & \\
\hline Regular Error Term $\left(\sigma_{\text {vit }}\right)$ & 2.7444 & \\
\hline No of observations (n) & 136 & \\
\hline Degree of freedom & 100 & \\
\hline Wald test for Heteroscedasticity ${ }^{1}$ & $1.9 * 10^{5 *}(.0000)$ & \\
\hline $\begin{array}{l}\text { Wooldridge Autocorrelation Test }{ }^{2} \text { AR } \\
\text { (1) }\end{array}$ & $.2940(.5914)$ & \\
\hline \multicolumn{3}{|c|}{$\begin{array}{l}\text { Note: }{ }^{1} \text { Wald test of heteroscedasticity has the null of no heteroscedasticity. }{ }^{2} \text { Wooldridge test of autocorrelation in panel has the } \\
\text { null of no autocorrelation (with } 1 \mathrm{lag} \text { ). } \sigma_{\text {vit }} \text { is remainder idiosyncratic error term. Theta estimates the fitness of random effect } \\
\text { model (higher is better). First value is coefficient followed by standard error. (value) has p-values. Robust estimates are } \\
\text { estimated due to significant Heteroscedasticity and Autocorrelation. DV is dependent variable. NPA is non-performing asset. } \\
\text { DR is dent ratio. DPR is dividend payment Ratio }{ }^{*} \text { sig at } 5 \% \text {. }{ }^{* *} \text { sig at } 10 \% \text {. }\end{array}$} \\
\hline
\end{tabular}

Table 1. Result of Panel Data Regression Analysis (Random Effect) 
The dynamic panel data results are reported in the Table 2. This study has many implications. It is well explicated by the Here as well, we find the problem of over-identification as findings of the paper that dividends are positively and null of no over-identification problem is rejected (test significantly linked to the NPA in the Indian banks. This statistics value is 8.7818 and p-value is .0124 which is untrammelled association of dividend with NPA need to be significant as $5 \%$ level of significance). Therefore, robust checked. This is not the ne plus ultra-approach for dividend estimates of standard are reported. DPR is significant with distribution. The findings of the paper can check and provide NPA. The lagged values of NPA is also significant with the the policy makers to devise newer ways to decide about the NPA. Whereas, debt-ratio as the control variable is not dividend policy. The problem of unscrupulous dividend could significant. It is recapitulated in the dynamic panel data be replaced by a well-articulated dividend policy in the estimates that DPR is significantly negatively associated with banks. This dialectical approach of dividend can be replaced NPA levels in the banks while controlling for the debt-ratio by a policy of linking dividends with the free cash flow. It is (long-term solvency).

\section{DISCUSSION}

The hypothesis framed in the study that there is no association between DPR and NPA is rejected as both the models (Table 1 and Table 2) find evidence that DPR is significantly associated with the NPA in the banks. This contribution is unique as no other study is observed which links the DPR with the NPA of the banks. not that the suggested dividend policy of linking it with free cash flow is bolt out of the blue. Whereas it is part of the ration approach for the dividend policy. It is not that this suggested policy will fly in the face of those shareholders who look for consistent dividend policy. Kernel of the truth is that this suggested policy should be in place all the time. The ultima ratio for catering to both set of investors is that there should be DVR (differential voting right) shares so that both type of investors will get the best of both the worlds (or approaches).

Table 2. Dynamic Panel Data Regression

\begin{tabular}{lcc}
\hline & DV: NPA & $\begin{array}{c}\text { DV: NPA } \\
\text { Robust Standard Error }\end{array}$ \\
\hline Constant & $-19.1093,17.7993(.2830)$ & $-19.1093,22.0153(.3850)$ \\
NPA (-1) & $-.7790^{*}, .1725(.000)$ & $-.7790^{*}, .3349(.0200)$ \\
DPR & $.0031^{*}, .0003(.0000)$ & $.0031^{*}, .00027(.0000)$ \\
DR & $28.5501,19.8672(.1510)$ & $28.5501,25.2755(.2590)$ \\
Sragan Test & $8.7818^{*}(.0124)$ & $8.7818^{*}(.0124)$ \\
Arnello-Bond AR (1) & $-.4429(.6578)$ & $-.4429(.6578)$ \\
\hline Note: NPA is the dependent variable. NPA (-1) is first lag of dependent variable as exogenous variable. DPR is \\
dividend pay-out ratio, which is an explanatory variable. DR is debt ratio, used here as control exogenous variable. \\
The null hypothesis of Sargan test is that there is no over-identification problem in dynamic panel data model. \\
Arnello-Bond test used in the analysis is for serial autocorrelation in the first differenced error terms of the order 1. \\
No autocorrelation is the Null of Arnello-Bond test. First value is coefficient, second value is standard error and p- \\
values are in parentheses (p-value).
\end{tabular}

\section{CONCLUSION}

This paper is on the NPA and dividend policy in the Indian banks. The findings of the paper accentuate that the dividend policy should add value to the shareholders and other stakeholder, not the other way round. Dividends are significantly affecting the NPA level is the testimony to the fact dividend policy does not add value to the banks in India. The allegiance of DPR with NPA while long-term solvency is controlled should be decoupled. Dividend should be linked to the profitability and performance of the firm, not a tool to bewitch the investors by the sham of high dividend pay-outs which may be a bereft of performance of the banks/firms. This paper does find out that dividends are linked to high non-performing assets. But, no policy on dividends is explored in the paper, which is a limitation of paper. A study on this line of inquiry would be a good future scope on the topic.

\section{REFERENCES}

1. Aivazian, V., Booth, L. \& Cleary, S. (2003), "Dividend policy and the organization of capital markets", Jr. of multinational financial mgmt., Vol. 13 No. 2, pp. 101-121.

2. Al-Malkawi, H.-a. N., Rafferty, M. \& Pillai, R. (2010), "Dividend policy: A review of theories and empirical evidence", Int. Bulletin of Business Administration,Vol. 9 No. 1, pp. 171-200.
3. $\quad$ Allen, F. \& Michaely, R. (1995), "Dividend policy", Handbooks in operations research and management science,Vol. 9 No. 1, pp. 793837.

4. Athaley, C., Rastogi, S., Goel, A. \& Bhimavarapu, V. (2020), "Factors Impacting Bank's Performance: A Literature Review", Test Engineering and Mgmt.,Vol. 83 No. May-June, pp. 7389-7398.

5. Baker, H. K. \& Smith, D. M. (2006), "In search of a residual dividend policy", Review of Financial Economics,Vol. 15 No. 1, pp. 1-18.

6. Bhimavarapu, V. M. \& Rastogi, S. (2020), "Valuation of Transparency-A Systematic Literature Review Paper", Test Engineering and Mgmt.,Vol. 83 No. May-June, pp. 9092-9102.

7. Bradley, M., Capozza, D. R. \& Seguin, P. J. (1998), "Dividend policy and cash-flow uncertainty", Real Estate Economics,Vol. 26 No. 4, pp. 555-580.

8. Byrd, D. T. \& Mizruchi, M. S. (2005), "Bankers on the board and the debt ratio of firms", Jr.of corporate finance,Vol. 11 No. 1-2, pp. 129-173.

9. DeAngelo, H. \& DeAangelo, L. (1990), "Dividend policy and financial distress: An empirical investigation of troubled NYSE firms", The Jr. of Finance,Vol. 45 No. 5, pp. 1415-1431.

10. Deshmukh, S. (2005), "The effect of asymmetric information on dividend policy", Quarterly Jr. of Business and Economics,Vol. 44 No. 1-2, pp. 107-128.

11. Gonzalez, F. (2005), "Bank regulation and risk-taking incentives: An international comparison of bank risk", Jr. of Banking \& Finance, Vol. 29 No. 5, pp. 1153-1184.

12. Ha, C. Y., Im, H. J. \& Kang, Y. (2017), "Sticky dividends: A new explanation", Finance Research Letters,Vol. 23 No. C, pp. 69-79.

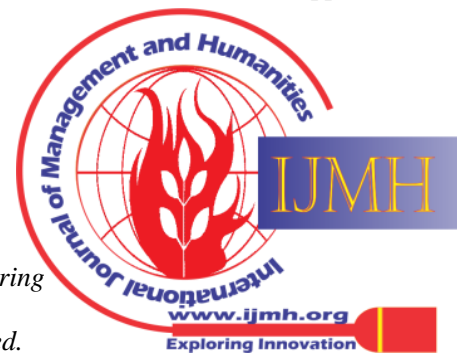




\section{Dividend and Bank Performance in India: Evidence using Panel Data Analysis}

13. Jo, H. \& Pan, C. (2009), "Why are firms with entrenched managers more likely to pay dividends?", Review of Accounting and Finance, Vol. 8 No. 1, pp. 87-116.

14. Kuknor, S. \& Rastogi, S. (2021), "Determinants Of Profitability In Indian Banks: A Panel Data Analysis", Int. Jr. of Modern Agriculture,Vol. 10 No. 2, pp. 978-986.

15. Pathak, R. \& Gupta, R. D. (2021), "The stability of dividends and its predictability: a cross-country analysis", Int. Jr. of Managerial Finance, https://doi.org/10.1108/IJMF-07-2020-0402.

16. Patil, A. C. \& Rastogi, S. (2019), "Time-Varying Price-Volume Relationship and Adaptive Market Efficiency: A Survey of the Empirical Literature", Jr. of Risk and Financial Mgmt.,Vol. 12 No. 2, pp. 1-18.

17. Patil, A. C. \& Rastogi, S. (2020a), "Multifractal Analysis of Market Efficiency across Structural Breaks: Implications for the Adaptive Market Hypothesis", Jr.of Risk and Financial Mgmt.,Vol. 13 No. 10, pp. 1-18.

18. Patil, A. C. \& Rastogi, S. (2020b), "Multifractal Analysis of TimeVarying Market Efficiency: Implications for Adaptive Market Hypothesis", Test Engineering and Mgmt.,Vol. 83 No. May-June pp. 16646-16660

19. Pinto, G. \& Rastogi, S. (2019), "Sectoral Analysis of Factors Influencing Dividend Policy: Case of an Emerging Financial Market", Jr. of Risk and Financial Mgmt.,Vol. 12 No. 3, pp. 110.

20. Pinto, G., Rastogi, S., Kadam, S. \& Sharma, A. (2019), "Bibliometric study on dividend policy", Qualitative Research in Financial Markets,Vol. 12 No. 1, pp. 72-95.

21. Rastogi, S. (2010a), "Interest Rate Futures in India: Future Trading and Spot market Volatility", Mgmt. Dynamics,Vol. 10 No. 2, pp. 67-81.

22. Rastogi, S. (2010b), "Volatility Spillover Effect Acrossbric Nations: An Empirical Study", Paradigm,Vol. 14 No. 1, pp. 1-6.

23. Rastogi, S. (2014), "The financial crisis of 2008 and stock market volatility-analysis and impact on emerging economies pre and post crisis", Afro-Asian Jr. of Finance and Accounting,Vol. 4 No. 4, pp. 443-459.

24. Rastogi, S. (2016), "Gold Future Market Efficiency Post 2007 Financial Crisis: An Empirical Study", Vishwakarma Business Review,Vol. 6 No. 2, pp. 30-39.

25. Rastogi, S. \& Agarwal, A. (2020), "Volatility Spillover Effect in Spot, Futures and Option Markets", Test Enginnering and Mgmt.,Vol. 83 No. May-June, pp. 10114-10127.

26. Rastogi, S. \& Athaley, C. (2019), "Volatility Integration in Spot, Futures and Options Markets: A Regulatory Perspective", Jr. of Risk and Financial Mgmt., Vol. 12 No. 98, pp. 1-15.

27. Rastogi, S., Goel, A. \& Doifode, A. (2020a), "Open API in Indian banking and economic development of the poor: opportunities and challenges", Int. Jr. of Electronic Banking,Vol. 2 No. 4, pp. 321 348.

28. Rastogi, S., Gupte, R. \& Meenakshi, R. (2021a), "A Holistic Perspective on Bank Performance Using Regulation, Profitability, and Risk-Taking with a View on Ownership Concentration", Jr. of Risk and Financial Mgmt., Vol. 14 No. 3, pp. 1-19.

29. Rastogi, S. \& Ragabiruntha, E. (2018), "Financial inclusion and socioeconomic development: gaps and solution", Int. Jr. of Social Economics,Vol. 45 No. 7, pp. 1122-1140.

30. Rastogi, S., Sharma, A. \& Panse, C. (2020b), "Open Banking and Inclusive Growth in India", Indian Jr. of Ecology,Vol. 47 No. SI9, pp. 75-79.

31. Rastogi, S., Sharma, A., Panse, C. \& Bhimavarapu, V. M. (2021b), "Unified Payment Interface (UPI): A Digital Innovation and Its Impact on Financial Inclusion and Economic Development", Universal Jr. of Accounting and Finance,Vol. 9 No. 3, pp. 518-530.

32. Rastogi, S., Suresh, V. \& Leonard, D. (2017), "FINANCIAL INCLUSION AND DEMONETIZATION: AN EMPIRICAL STUDY USING EXPLORATORY FACTOR ANALYSIS", Indian Jr. of Commerce and Mgmt. Studies,Vol. 8 No. 1(5), pp. 38-46.

33. Sarkar, A. \& Rastogi, S. (2011), "Impact of gold and silver futures on the spot rate volatility: An Indian perspective", Nice Jr. of Business,Vol. 6 No. 1, pp. 23-28.

34. Sharma, A. \& Rastogi, S. (2020), "SPOT VOLATILITY PREDICTION BY FUTURES AND OPTIONS: AN INDIAN SCENARIO", Int. Jr. of Modern Agriculture,Vol. 9 No. 3, pp. 263 268.

35. Sharma, A. \& Rastogi, S. (2021), "Impact of Efficiency on Voluntary Disclosure of Non-Banking Financial CompanyMicrofinance Institutions in India", Jr. of Risk and Financial Mgmt.,Vol. 14 No. 7, pp. 289-311.

36. Sharma, A., Rastogi, S. \& Gupta, N. (2020), "Financial Efficiency of Non-Banking Financial Companies-Microfinance Institutions: A

Published By:

Blue Eyes Intelligence Engineering \& Sciences Publication
37. Singh, I. \& Rastogi, S. (2020), "Drivers impacting bank risk in India", Test Engineering and Mgmt.,Vol. 83 No. May-June, pp. 8005-8011.

38. Singh, S., Rastogi, S. \& Bhimavarapu, V. M. (2020), "DO INFORMED INVESTORS PREFER FUTURES?", Int. Jr. of Modern Agriculture,Vol. 9 No. 3, pp. 257-262.

\section{AUTHORS PROFILE}

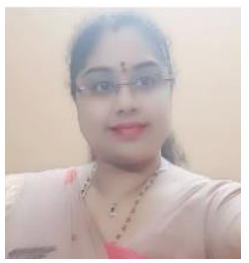

Venkata Mrudula Bhimavarapu, currently pursuing $\mathrm{PhD}$ as a full-time research scholar at the Symbiosis International (Deemed University). She is an MBA gold medallist from the Andhra University and MPhil in Financial Management from Annamalai University. She has around 7 years of experience in the field of academics and research. She has presented papers in national level conferences.

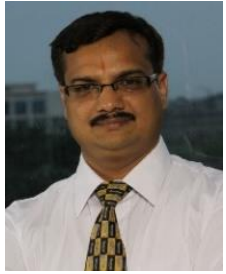

Dr. Shailesh Rastogi, is presently working as a professor at SIBM Pune. He has more than 20 years of experience of academics and industry. His areas of expertize include conducting MDPs on Panel Data Econometrics, Financial Econometrics, Financial Analytics using spreadsheet \& VB and Corporate Valuation. He is a prolific researcher and has more than 70 research papers published in the national and international journal of repute 